OPEN ACCESS

Edited by:

Nathaniel R. Warner, Pennsylvania State University (PSU),

United States

Reviewed by:

Pankaj K. Gupta,

University of Waterloo, Canada

Argaw Ambelu,

Jimma University, Ethiopia

*Correspondence:

Augustine O. Edegbene ovieedes@gmail.com

TORCID:

Augustine O. Edegbene orcid.org/0000-0003-4032-3923

Francis O. Arimoro orcid.org/0000-0001-6100-4011

Oghenekaro N. Odume orcid.org/0000-0001-5220-3254

Efe Ogidiaka

orcid.org/0000-0002-6279-0576

Unique N. Keke

orcid.org/0000-0002-9528-0599

Specialty section

This article was submitted to Environmental Water Quality,

a section of the journal

Frontiers in Water

Received: 17 September 2020

Accepted: 26 January 2021

Published: 02 March 2021

Citation:

Edegbene AO, Arimoro FO,

Odume ON, Ogidiaka E and Keke UN

(2021) Can Macroinvertebrate Traits

Be Explored and Applied in

Biomonitoring Riverine Systems

Draining Forested Catchments?

Front. Water 3:607556.

doi: 10.3389/frwa.2021.607556

\section{Can Macroinvertebrate Traits Be Explored and Applied in Biomonitoring Riverine Systems Draining Forested Catchments?}

\author{
Augustine O. Edegbene ${ }^{1 * t}$, Francis O. Arimoro ${ }^{2 t}$, Oghenekaro N. Odume ${ }^{1 \dagger}$, Efe Ogidiaka ${ }^{3 t}$ \\ and Unique N. Keke ${ }^{2 t}$ \\ ${ }^{1}$ Unilever Centre for Environmental Water Quality, Institute for Water Research, Rhodes University, Grahamstown, South \\ Africa, ${ }^{2}$ Applied Hydrobiology Unit, Department of Animal Biology, Federal University of Technology, Minna, Nigeria, \\ ${ }^{3}$ Department of Fisheries and Fisheries Technology, School of Science and Technology, Delta State School of Marine \\ Technology, Burutu, Nigeria
}

Trait-based approach (TBA) in recent time has received tremendous attention as complementary tool over taxonomic-based approach in assessing ecological health of riverine systems in developed countries, but in the Afrotropical region the trait-based approach is still in its infancy. No trait-based approach has been developed for riverine systems draining forested catchment in the Afrotropical region. Hence, this study was conducted to explore and apply macroinvertebrates traits as potential biomonitoring tools in assessing ecological health of riverine systems draining forested catchments in the Niger Delta area of Nigeria. Selected physico-chemical variables were sampled together with macroinvertebrates in 18 stations of 10 riverine systems from 2008 to 2012. The 18 stations were classified into three ecological classes namely near natural stations (NNS), slightly disturbed stations (SDS), and moderately disturbed stations (MDS) using physico-chemical-based classification with the aid of principal component analysis (PCA). The results revealed traits such as possessions of hardshell body armouring, preferences for clear and transparent water and opaque water, climbing and crawling mobility mechanisms, large (>20-40 mm) body size, preferences for scrapping, shredding, and grazing feeding habits to be associated with NNS and SDS based on $R L Q(R$, physico-chemical variables; L, taxa; $Q$, traits) analysis performed. Thus, these traits were deemed to be sensitive to human impact in forested systems. Also, traits such as tegument/cutaneous respiration, soft and exposed body armouring, burrowing mobility mechanism, spherical body shape, preference for detritus [fine particulate organic materials (FPOM)] food materials, small $(>5-10 \mathrm{~mm}$ ) body size and preference for filter feeding mechanism were associated with MDS. Hence, they were deemed tolerant of human impact in forested systems. A fourth-corner test performed revealed tegumental/cutaneous respiration preference, soft and exposed body armouring and burrowing mobility mode, which were associated with the MDS on the RLQ ordination were also positively correlated to 5 day biochemical oxygen demand $\left(\mathrm{BOD}_{5}\right)$; while preference for clear and transparent water, which were positively associated with MDS, were also positively correlated with $\mathrm{pH}$ and negatively correlated to dissolved 
oxygen (DO). Overall, this study affirmed that the TBA can be explored in biomonitoring riverine systems draining forested catchments. Nevertheless, we suggest the trait-based approach to be further explored, with a view to developing trait-informed indices for biomonitoring Afrotropical riverine systems.

Keywords: forestry, trait-based approach, functional feeding groups (FFGs), ecological classes, RLQ and fourthcorner analyses, Niger Delta, Nigeria

\section{INTRODUCTION}

Trait-based approach has recently gained attention as complementary to taxonomy-based approach when assessing riverine water quality (Fierro et al., 2017; Krynak and Yates, 2018; Desrosiers et al., 2019). The trait-based approach is engrained on the Habitat Template Concept (HTC) postulated by Townsend and Hildrew (1994). The HTC states that organisms survive in ecosystems where they possess the appropriate traits combinations, allowing them to adapt, and thrive in their external environments (Townsend and Hildrew, 1994). For instance, the possession of rapid reproductive turn-over has been postulated to confer resilience on organism in disturbed riverine systems (Townsend and Hildrew, 1994; Edegbene et al., 2020a). With regard to forested riverine systems receiving allochthonous materials from surrounding riparian vegetation, functional feeding groups (FFGs) such as shredders would dominate such systems providing a non-taxonomy based approach for assessing functional changes along the river length (Vannote et al., 1980; Moares et al., 2014; Brand and Miserendino, 2015).

Vannote et al. (1980) in their popular river continuum concept postulated the proportional distribution of functional feeding groups from forested systems dominated by allochthonous production to open system dominated by autochthonous production, shredders adapted for breaking down coarse particulate organic matter (CPOM) are expected to be dominant in forested system, whereas collector-gatherers and filter-filter feeders, which are adapted for consuming fine particulate organic materials (FPOM) are expected to be dominant in large open river systems (Vannote et al., 1980; Edegbene, 2020).

Although the trait-based approach is being increasingly applied for biomonitoring purposes (Statzner and Beche, 2010; Castro et al., 2018), the taxonomy-based approach is still widely used in the assessment of ecological status of riverine systems (e.g., Tonkin et al., 2016; Arimoro and Keke, 2017; Krynak and Yates, 2018; Edegbene et al., 2019a,b). In this regard, macroinvertebrates taxonomic structures are the most explored due to their important position in aquatic food web, their easy collection, and well-established biomonitoring protocols (Bonada et al., 2006). The taxonomybased approach takes into account the structural distribution of the abundance, diversity, and composition of aquatic macroinvertebrates in relation to environmental stress (McGill et al., 2006). However, one of the short coming of this approach is that taxonomy is geographically constrained and often requires adaptation when applied across multiple distant geographical spaces (Edegbene et al., 2020a; Odume, 2020). In the Afrotropical context, identification of macroinvertebrates remains a challenge due to scarcity of taxonomic expertise further compounding the utility of the taxonomy-based approach to freshwater biomonitoring. Some authors such as Akamagwuna et al. (2019), Edegbene et al. (2020a,b), and Odume (2020) have thus call for the development of the traitbased approach to complement the taxonomy-based approach in the Afrotropical region.

Globally, the trait-based approach has grown in popularity for assessing and monitoring riverine health (e.g., Statzner and Beche, 2010; Descloux et al., 2014; Kuzmanovic et al., 2017; Serra et al., 2017; White et al., 2017; Berger et al., 2018; Castro et al., 2018; Krynak and Yates, 2018; Milosevic et al., 2018; Desrosiers et al., 2019), but only few studies have attempted to develop and apply the trait-based biomonitoring approach for assessing riverine systems health in the Afrotropical region (e.g., Akamagwuna et al., 2019; Edegbene et al., 2020a,b; Odume, 2020). The studies of traits in the Afrotropical region have focused largely on assessing freshwater systems subject to urban, agricultural, and industrial pollution. For instance, Odume (2020) developed trait-based approach for monitoring a river system in an urbanized and industrialized catchment in South Africa. Apart from the use of FFGs, the trait-based approach has not been applied to forested systems. In the present study, we explore the possibility of using macroinvertebrates traits for biomonitoring riverine systems draining forested catchments in the Niger Delta area of Nigeria.

Most of the riverine systems in the Niger Delta area of Nigeria drain forested catchments with patches of mangrove swamps dominated by red and white mangroves (Adekola and Mitchell, 2011; Edegbene et al., 2019b). The area is internationally recognized as a biodiversity hotspot (Tonkin et al., 2016). Despite the ecological importance of the area, most of the studies conducted in assessing the ecological status of riverine systems within the area is still centered on the use of aquatic biota composition, diversity and abundance (Edegbene and Arimoro, 2012; Arimoro et al., 2015). No study has been conducted to explore the importance of using macroinvertebrates traits in assessing and monitoring the ecological status of the forested riverine systems within the Niger Delta area. Therefore, the question was asked "Can macroinvertebrate traits be explored and applied for biomonitoring riverine systems draining forested catchments?" In the light of this question, the aim of this study was to explore and apply macroinvertebrate traits in biomonitoring riverine systems draining forested catchments in the Niger Delta region of Nigeria. 


\section{MATERIALS AND METHODS}

\section{The Study Area}

The Niger Delta area of Nigeria is a tropical rain forest belt which occupies an area $\sim 70,000 \mathrm{~km}^{2}$ in the Southern region of
Nigeria (Edegbene et al., 2020a). The area is located within the interception of $5^{\circ} 27^{\prime}-6^{\circ} 50^{\prime} \mathrm{N}$ and $5^{\circ} 35^{\prime}-6^{\circ} 41^{\prime} \mathrm{E}$ of the equator (Tonkin et al., 2016; Edegbene et al., 2020a). The area is dominated by rainforest, mangrove and freshwater swamps (Tonkin et al., 2016). The forests are characterized by dense

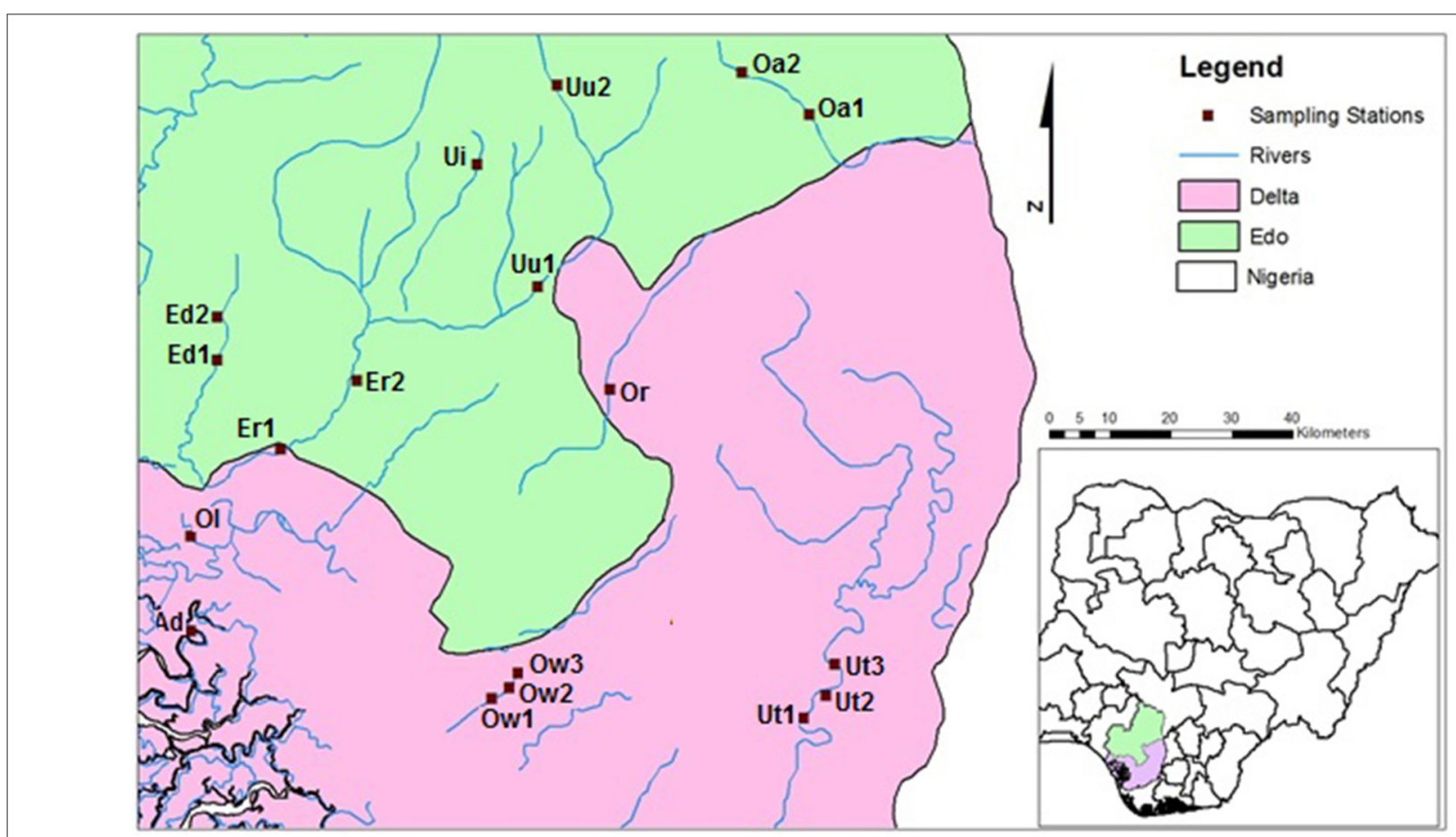

FIGURE 1 | Map of the study area showing the sampled stations.

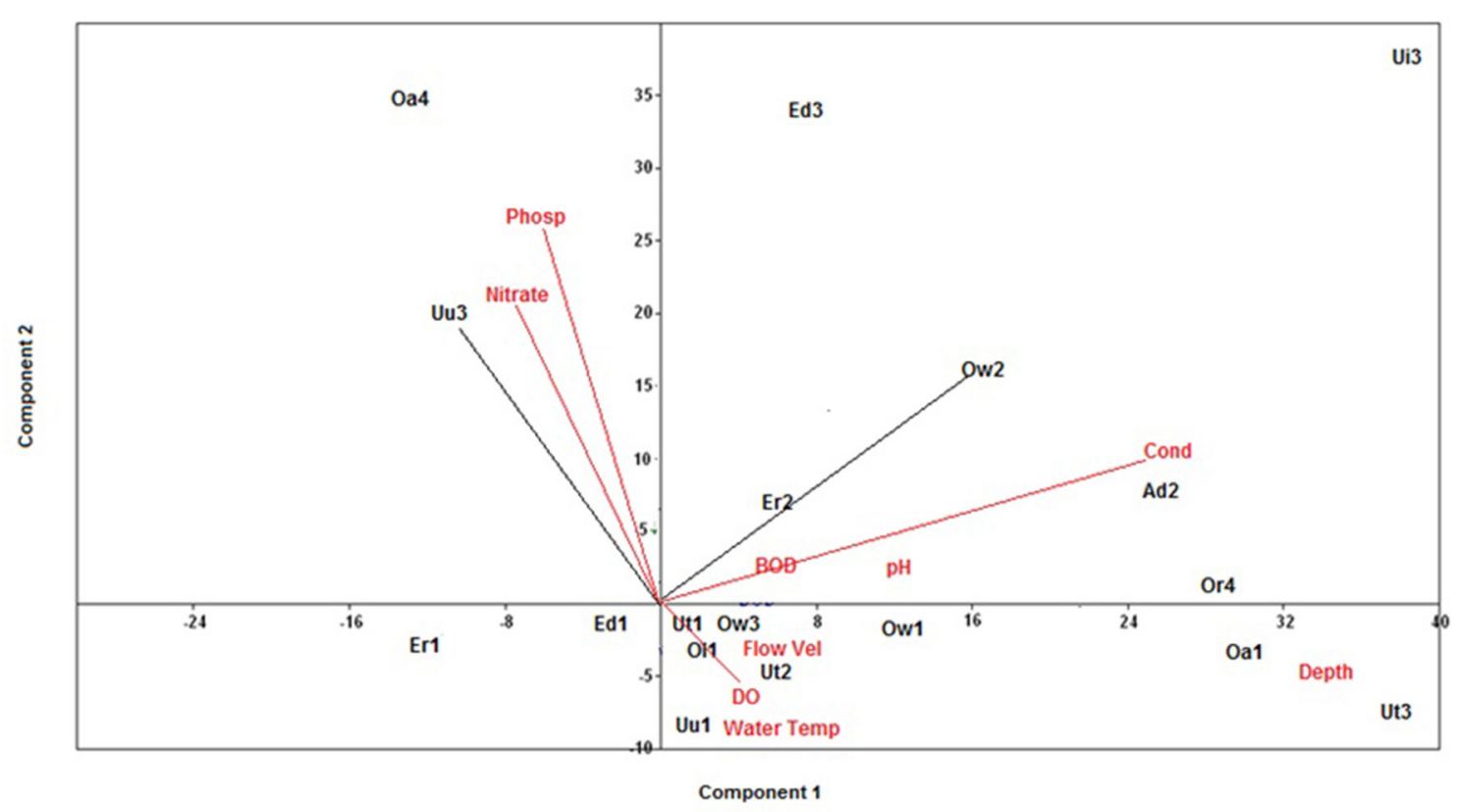

FIGURE 2 | PCA visualizing the 18 stations correlation with selected physico-chemical variables. Water Temp, Water temperature; Flow Vel, Flow velocity; DO, Dissolved oxygen; BOD, 5-day biochemical oxygen demand; Cond, Electrical conductivity; Phosp, phosphate. 
canopy of trees which include Pandanus spp., Bambusa spp., Mitragyna spp., and Elaeis spp. (Tonkin et al., 2016). Two major seasons characterized the area (wet and dry) seasons. The wet season is between March and September, while the dry season is between October and February (Edegbene and Arimoro, 2012). In-between the dry season month of December and February, a short season called harmattan sets-in with relatively cold weather condition of an average temperature of $10^{\circ} \mathrm{C}$.

\section{Study Rivers and Stations}

Eighteen (18) sampling sites located in 10 riverine systems draining forested catchments were selected for the study (Figure 1). The sampled rivers include Rivers Umu (Uu1, Uu2), Utor (Ut1, Ut2, Ut3), Edor (Ed1, Ed2), Ogbomwen (Ow1, Ow2, Ow3), Orogodo (Or), Oleri (Ol), Adofi (Ad), Eriora (Er1, Er2), Owan (Oa1, Oa2), and Umoni (Ui) Rivers.

\section{Physico-Chemical Variables and Macroinvertebrates Sampling and Analysis}

In the course of this study, physico-chemical variables were measured in each station once monthly from 2008 to 2012 (5 years). The physico-chemical variables sampled and analyzed for this study include water temperature, flow velocity, depth, electrical conductivity (EC), dissolved oxygen (DO), 5day biochemical oxygen demand $\left(\mathrm{BOD}_{5}\right), \mathrm{pH}$, nitrate, and phosphate. Details on how physico-chemical variables were measured and analyzed for this study are contained in an earlier publication conducted by Edegbene et al. (2019b).

Macroinvertebrates samples were also collected at each sampling station along with physico-chemical variables for the 5 years period. Collection of macroinvertebrates were done using kick net of $500 \mu \mathrm{m}$ mesh size as earlier described by Lazorchak et al. (1998). Also details on macroinvertebrates

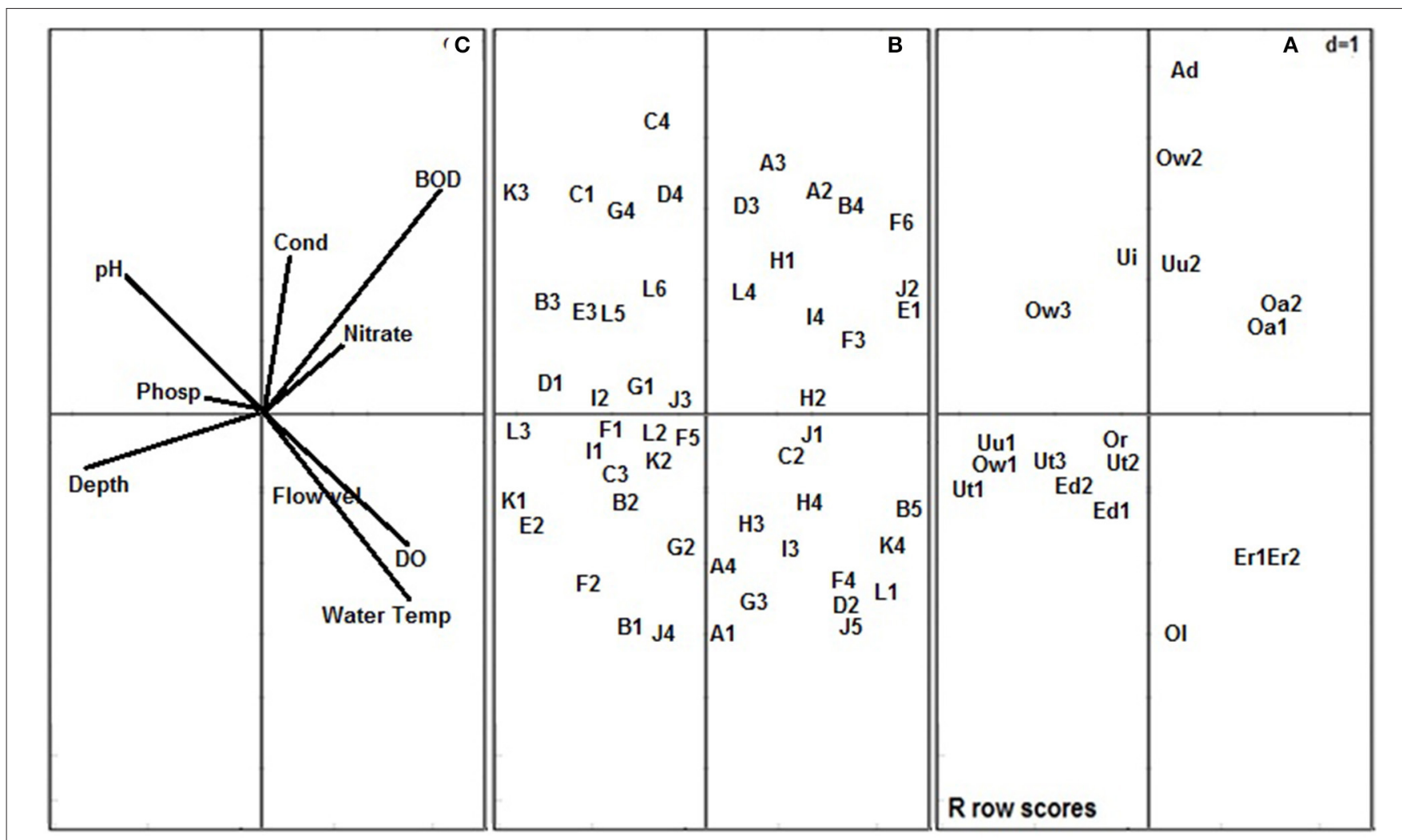

FIGURE 3 | Co-variation of the 18 river stations (A), macroinvertebrate traits (B) and physico-chemical variables (C) along the first two components of the RLQ. Stations: Uu1, Umu River Station 1; Uu2, Umu River Station 2; Ut1, Utor River Station 1; Ut2, Utor River Station 2; Ut3, Utor River Station 3; Ed1, Edor River Station 1; Ed2, Edor River Station 2; Ow1, Ogbonwen River Station 1; Ow2, Ogbonwen River Station 2; Ow3, Ogbonwen River Station 3; Ol, Oleri River; Or, Orogodo River; Ad, Adofi River; Er1, Eriora River Station 1; Er2, Eriora Station 2; Oa1, Owan River Station 1; Oa2, Owan River Station 2; Ui, Umoni River. Physico-chemical variables: Water Temp, Water Temperature; Flow, Flow velocity; DO, Dissolved oxygen; BOD, 5 day biochemical oxygen demand; Cond, Electrical conductivity; Phosp, Phosphate. Stations ecological classes: NNS, near natural stations; SDS, slightly disturbed stations; MDS, moderately disturbed stations. Macroinvertebrate traits: "A1, Gills; A2, Tegumental/cutaneous; A3, Aerial: spiracle; A4, Aerial/vegetation: breathing tube, strap/other apparatus; B1, Hardshell; B2, Completely sclerotized; B3, Partly sclerotized; B4, Soft and exposed; B5, Cased/tubed; C1, Clear and transparent waters; C2, Silty; C3, Turbid waters; C4, No preference; D1, 1 year (Univoltine); D2, 2 years (Bivoltine); D3, > 2 years (Multivoltine); D4, longer than 1 year (Semivoltine); E1, Free-living; E2, Temporary attachment; E3, Permanent attachment; F1, Climbing; F2, Crawling; F3, Sprawling; F4, Swimming; F5, Skating; F6, Burrowing; G1, Streamlined; G2, Flattened; G3, Spherical; G4, Cylindrical/tubular; H1, Detritus (FPOM); H2, Detritus (CPOM); H3, Macrophytes/algae; H4, Animal materials; I1, Highly sensitive to oxygen depletion; I2, Moderately sensitive to oxygen depletion; I3, Moderately tolerant of oxygen depletion; 14, Highly tolerant of oxygen depletion; J1, Very small (<5 mm); J2, Small (>5-10 mm); J3, Medium (>10-20 mm); J4, Large body size (>20-40 mm); J5, Very large body size (>40-80 mm); K1, Egg; K2, Larva aquatic stage; K3, Nymph aquatic stage; K4, Pupa aquatic stage; L1, Predating; L2, Scraping; L3, Grazing; L4, Filter feeding; L5, Deposit feeding; L6, Shredding" (Edegbene et al., 2020b). 
collection, processing, sorting, identification, and enumeration are contained in an earlier publication by Edegbene et al. (2019b).

\section{Statistical and Data Analyses \\ Station Ecological Classification Using Physico-Chemical Variables}

The 18 stations sampled during the sampling period were ecologically classified by visualizing the correlation between selected physico-chemical variables and sampled stations using principal component analysis (PCA; Figure 2). The PCA ordination was computed using vegan package within the Rprogramming language (Oksanen et al., 2019) details of the actual station ecological classification was done following earlier method employed by Murphy et al. (2013), Edegbene et al. (2019b, 2020a).

\section{Macroinvertebrate Traits}

In this study 12 traits, divided into 53 traits attributes were selected. The 12 traits were those related to body size, body shape, body armouring, respiration, turbidity preference, voltinism, attachment mechanism, mobility, feeding preference, sensitivity to organic pollution, aquatic stages, and feeding habit (see Figure 3) for list of selected traits attributes. Most of these traits have been reported to be suitable for assessing various kinds of human disturbances. Traits information were primarily obtained from available literature containing traits information in Nigeria (Edegbene et al., 2020a), and supplemented and confirmed by traits literature information from elsewhere (Odume et al., 2018).

The selected macroinvertebrate traits link with each macroinvertebrate taxon was affirmed by fuzzy coding method (Chevenet et al., 1994). Fuzzy coding method shows the trait affinity with each taxon, and it accounts for any possible functional differences that may occur among species within the same taxon (Odume, 2020). Further, the fuzzy coding method compensates for any variation that would come with the allocation of a given taxon to a trait attribute (Mondy and Usseglio-Polatera, 2014). An affinity score of 0-3 was awarded to describe the taxon affinity to a given trait (Chevenet et al., 1994). A taxon is awarded a score of 0 if it shows no affinity to a given trait, while scores of 1,2 , and 3 was awarded to a taxon if it shows low, moderate and high affinity, respectively to a given trait (Chevenet et al., 1994). In processing the collated trait affinity, each trait score was multiplied by the relative abundance of the macroinvertebrate taxon.

\section{Exploring Macroinvertebrate Traits Distribution}

To explore macroinvertebrate traits distribution patterns in the forested riverine systems, an RLQ ordination plot was performed. The RLQ is a multivariate ordination which was developed by Dolédec et al. (1996), and it performs an ordination on three datasets: environmental variables e.g., physico-chemical variables (R), taxa (L), and traits (Q). In this study, the RLQ ordination was used to relate physico-chemical variables (R), macroinvertebrates

TABLE 1 | Stations ecological classification in the present study.

\begin{tabular}{|c|c|c|c|c|c|}
\hline Rivers/station codes & $\begin{array}{l}\text { Near natural stations } \\
\text { (NNS) }\end{array}$ & $\begin{array}{l}\text { Slightly disturbed } \\
\text { stations (SDS) }\end{array}$ & $\begin{array}{l}\text { Moderately disturbed } \\
\text { stations (MDS) }\end{array}$ & Catchment size $\left(\mathrm{km}^{2}\right)$ & Land use type \\
\hline Uu1 & $x$ & & & 104 & Forestry \\
\hline Ut1 & $X$ & & & 3,598 & Forestry \\
\hline Ut2 & $x$ & & & 4,480 & Forestry/Urbanization \\
\hline Ut3 & & $x$ & & 4,483 & Forestry/Urbanization \\
\hline Ed1 & & $x$ & & 77 & Forestry \\
\hline Ow1 & & $x$ & & 525 & Forestry \\
\hline Ow3 & & $x$ & & 531 & Forestry \\
\hline Or & & $x$ & & 681 & Forestry/Urbanization \\
\hline Ol & & $x$ & & 431 & Forestry \\
\hline $\mathrm{Ad}$ & & & $x$ & 339 & Forestry \\
\hline Ed2 & & & $X$ & 530 & Forestry \\
\hline Er1 & & & $x$ & 42 & Forestry \\
\hline Er2 & & & $x$ & 61 & Forestry \\
\hline Oa1 & & & $x$ & 6,184 & Forestry/Urbanization \\
\hline Oa2 & & & $x$ & 6,221 & Forestry/Urbanization \\
\hline Ow2 & & & $x$ & 511 & Forestry \\
\hline Ui & & & $x$ & 57 & Forestry \\
\hline Uu2 & & & $x$ & 839 & Forestry \\
\hline
\end{tabular}


taxa (L), the traits (Q), and sampled stations. The RLQ first two components were tested for statistical significance using the Monte Carlo permutation test at 999 permutations argument $(P=0.05)$.

Macroinvertebrate traits relationships with physico-chemical variables were evaluated using a multivariate test known as fourth-corner test. The fourth-corner test shows the association between traits and physico-chemical variables. The test shows traits that show positive, negative or no association with given physico-chemical variables.

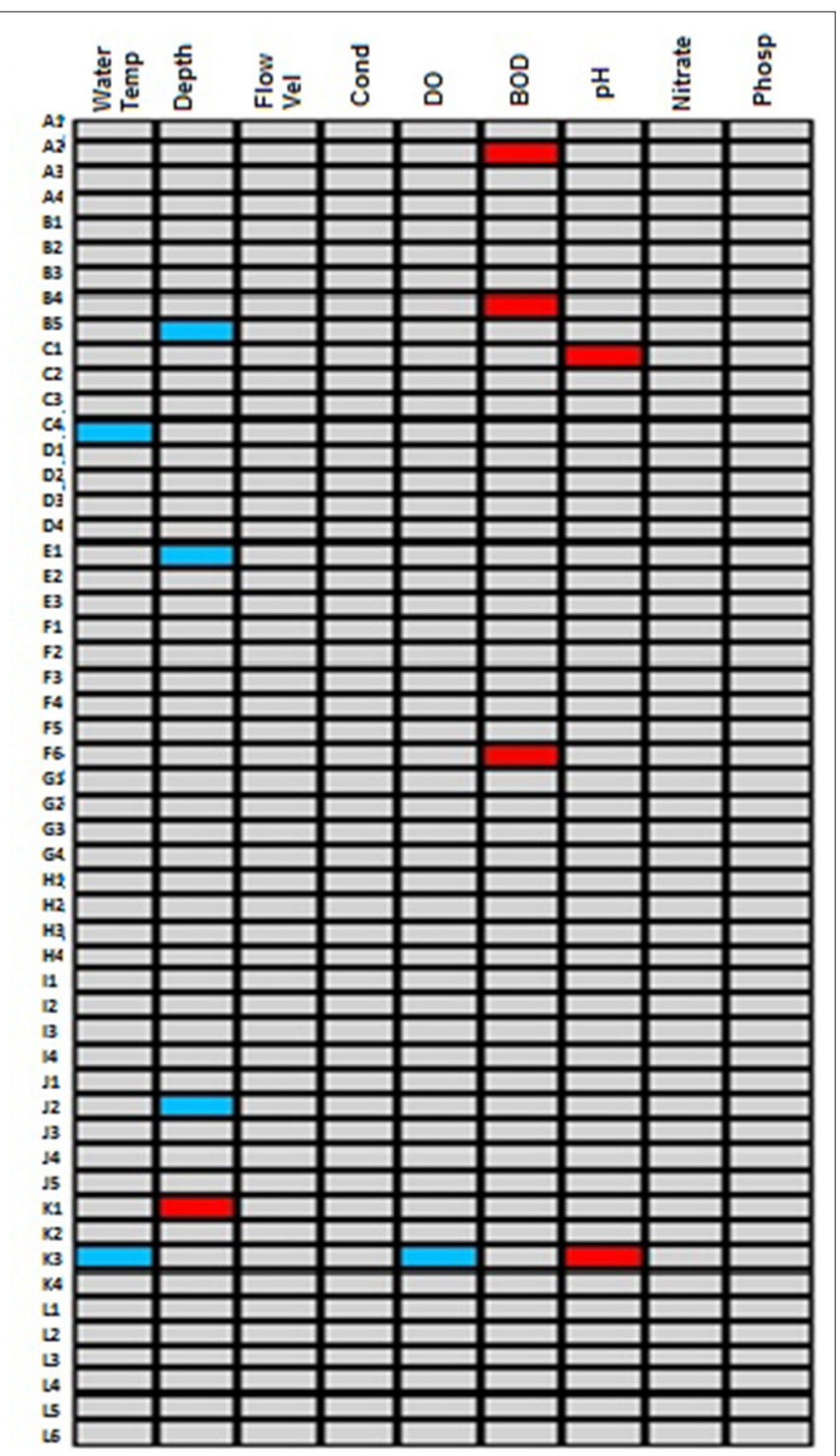

FIGURE 4 | Summary of the fourth-corner test performed for macroinvertebrates traits and physico-chemical variables in the selected riverine systems draining forested catchment. Significant positive relationships are shown in red colored cells while the significant negative correlations are shown in blue colored cells. The gray colored cells represent no-significant relationships.

\section{RESULTS}

\section{Stations Ecological Classification Using Physico-Chemical Variables}

From the results of the PCA ordination, Component 1 and 2 had Eigen values of 456.2 and 101.9, respectively. Station 1 of Edor and Eriora Rivers were positioned on Component 2 and they had no correlation with any physico-chemical variable (Figure 2). Positioned on Component 1 of the PCA were Oleri River, Stations 1 of Ogbonwen, Owan, and Utor Rivers, Station 3 of Rivers Ogbonwen, and Stations 2 and 3 of Utor Rivers which were correlated with $\mathrm{DO}$, flow velocity, water temperature, and depth (Figure 2). $\mathrm{BOD}_{5}$, electrical conductivity (EC), and $\mathrm{pH}$ were positively correlated with Adofi River, Stations 2 of Eriora and Ogbonwen Rivers, Edor, Eriora, Utor Rivers, and Orogodo River, and they were positioned on Component 1. Station 2 of Owan and Umu Rivers were correlated with nitrate and phosphate on Component 2 (Figure 2).

The classification of stations into ecological classes was undertaken by correlating sampled stations with physicochemical variables. Initially, stations associating with physicochemical variables indicating pollution (e.g., EC, $\mathrm{BOD}_{5}$, nitrate, and phosphate) were classified as disturbed stations, while stations associating with physico-chemical variables indicating good water quality (e.g., DO) were classified as non-disturbed stations. The actual stations ecological classification in this study was done by extracting the coordinate values of each station from the first component of the PCA. Further, the inter-station distances of each station were calculated following the methods earlier employed by Murphy et al. (2013). In adopting the methods employed by Murphy et al. (2013), the 18 stations were classified into three ecological classes, which include near natural stations (NNS), slightly disturbed stations (SDS), and moderately disturbed stations (MDS). The first component of the PCA was adopted for computing station ecological classes because it explained the highest percent variation $79 \%$ compared to the second component which explained $17.7 \%$ percent variation of the PCA (Murphy et al., 2013). Similar methods have recently been used by Edegbene et al. (2019b, 2020a) to classify sites into ecological categories along urban and agricultural pollution gradients. The stations classes are shown in Table $\mathbf{1}$.

\section{Exploring the Distribution Patterns of Macroinvertebrate Traits}

The NNS (Station 1 of Umu and Utor Rivers and Station 2 of Utor River) and SDS (Station 1 of Edor and Ogbonwen, Station 3 of Utor and Orogodo Rivers) were associated with Component 1 while all the MDS except Stations 2 of Edor River were associated with Component 2 on the RLQ ordination plane (Figure 3). Positioned at the center of the RLQ biplot were Oleri and Umoni Rivers. Stations classified as NNS and SDS at Component 1 were positively correlated with $\mathrm{pH}$, phosphate and water depth, while stations classified as MDS which were associated with Component 2 and were positively correlated with decreased concentration of $\mathrm{BOD}_{5}, \mathrm{EC}$, and nitrate (Figure 3 ).

Traits that were associated with the NNS and SDS include the possessions of hardshell, complete sclerotization of the body, 
partial sclerotization of the body, preferences for clear and transparent waters and turbid waters, 1 year (univoltinism), longer than 1 year (semivoltinism), preferences for temporary and permanent attachment, climbing and crawling, flattened body shape, cylindrical/tubular body shape, preferences for a high and moderate sensitivity to oxygen depletion, large (>20$40 \mathrm{~mm}$ ) body size, preferences for scrapping, shredding, and grazing feeding habits and nymph aquatic stage (Figure 3). Thus, signifying their sensitivity to impact in forested systems. Further, traits that were associated with the MDS include tegumental/cutaneous respiration, soft and exposed body, a preference for free-living, burrowing, spherical body shape, a preference for detritus (FPOM) as food materials, small body size $(>5-10 \mathrm{~mm})$, and a preference for filter feeding (Figure 3). Hence, proving their tolerance to impact in forested systems.

The Eigen values of the first two components of the RLQ were 3.89 and 1.39, respectively, and the RLQ Component 1 explained $65.74 \%$ variation, while Component 2 explained 22.93\%. A projected total inertia of 6.057 was recorded while a variance for physico-chemical variables for Components 1 and 2 were 3.39 and 5.42, respectively and the traits variance for Component 1 was 19.60 and Component 2 was 12.21 . There was no statistically significant difference between the macroinvertebrates traits and physico-chemical variables $(P>0.05)$ as revealed by a MonteCarlo test at 999 permutations.

To further confirms traits sensitivity to and tolerant of impact in forested systems, a fourth-corner test was performed after the RLQ ordination in a bid to further explore the traits correlation with physico-chemical variables. The result revealed that a preference for tegumental/cutaneous respiration, soft and exposed body and burrowing, which were associated with the MDS on the RLQ ordination were also positively correlated with $\mathrm{BOD}_{5}$ on the fourth-corner test (Figure 4). This further confirms their tolerance of human impact in forested systems owing to their positive relationship with $\mathrm{BOD}_{5}$ a pollution indicating physico-chemical variable. On the other hand, preference for clear and transparent waters and nymph aquatic stage which were positively associated with MDS on the RLQ ordination were also positively correlated with $\mathrm{pH}$ on the fourth-corner test (Figure 4), while only preference for clear and transparent waters was negatively correlated to DO.

\section{DISCUSSION}

The present study explored the possibility of biomonitoring riverine systems draining forested catchments in the Niger Delta area of Nigeria using macroinvertebrate trait-based approach. The results revealed traits such as preferences for clear and transparent water, univoltinism, semivoltinsim, preferences for climbing and crawling, flattened body shape, cylindrical/tubular body shape, preferences for high and moderate oxygen depletion, large body size (>20-40mm), preferences for scrapping, grazing and shredding to be associated with near natural stations (NNS), and slightly disturbed stations (SDS). The distributions of these traits were defined by decreased $\mathrm{pH}$, phosphate, $\mathrm{BOD}_{5}, \mathrm{EC}$, and nitrate concentration, suggesting that they are sensitive to impact in forested systems. Most of the traits associated with
NNS and SDS have been reported to be positively correlated with decreased pH (Moyo and Richoux, 2017), and decreased concentrations of some pollution-indicating physico-chemical variables such as $\mathrm{BOD}_{5}, \mathrm{EC}$, nitrate, and phosphate (Edegbene et al., 2020a). Thus, these traits are overall sensitive to increasing human impacts in forested systems and their disappearance should thus serves as a warning signal. The results pertaining to the distribution of these traits are similar to those reported by Guilpart et al. (2012), Pallottini et al. (2017), and Milosevic et al. (2018) indicating that traits such as shredding and scrapping were associated with riverine stations close to natural condition. Functional feeding groups (FFGs) are commonly used for assessing disturbances in forested systems (Stepenuck et al., 2002; Mondy and Usseglio-Polatera, 2014). As with other studies, the results in this study suggest that shredders and scrappers are sensitive to impact in forested systems. Shredders are particularly sensitive to changes in the type and quality of leaf litters due to human impact on forest (Stepenuck et al., 2002; Mondy and Usseglio-Polatera, 2014). Fierro et al. (2017) and Kuzmanovic et al. (2017) had reported forested riverine systems receiving allochthonous materials from surrounding riparian vegetation to be dominated by organisms that are shredders, scrappers and collector-gatherers. Therefore, from a biomonitoring perspective, relative change of shredders and scrappers can serve as good indicators of water quality impact in forested systems. This is particularly so because these organisms are sensitive to changes in allochthonous inputs (Vannote et al., 1980; Moares et al., 2014; Brand and Miserendino, 2015). This finding showed that functional traits can be used to assess whether riverine systems within the Niger Delta area of Nigeria are near to natural conditions or disturbed. Furthermore, owing to the continuous urbanization of the Niger Delta area, the outlined functional traits would serves as gauge to separate rivers that are perturbed from those that are unperturbed.

Macroinvertebrate taxa with large body size ( $>20-40 \mathrm{~mm})$ were associated with NNS and SDS on the RLQ ordination. This finding in the present study is in line with the prediction of the habitat template concept (HTC), which affirms that organisms with large body size associates more with sites that are less disturbed (Townsend and Hildrew, 1994). Organisms with large body size have been reported to possess a reduced surface area to volume ratio, which makes them vulnerable to disturbances (Townsend and Hildrew, 1994; Edegbene et al., 2020a).

Traits such as tegumental/cutaneous respiration, soft and exposed body, burrowing, possession of a small body size ( $>5-10 \mathrm{~mm})$, preferences for free-living and filter feeding were associated with moderately disturbed stations (MDS) on the RLQ ordination and they were positively correlated with decreasing dissolved oxygen concentrations. Organisms that exhibit tegumental/cutaneous are less sensitive to depletion in dissolved oxygen because of their efficiency in gaseous exchange with their external environment. These organisms are often reported in disturbed sites (Lamouroux et al., 2004; Tomanova and Usseglio-Polatera, 2007; Tomanova et al., 2008; Desrosiers et al., 2019). Similarly, specialist burrowers are also able to tolerate fluctuation in vertical DO saturation, enabling them to cope in systems that are depleted in dissolved oxygen. Overall, the use of tegumental/cutaneous for respiring as well as a 
preference for burrowing seems to be tolerant of human impact in forested systems. These suggestions are in line with those of Lamouroux et al. (2004), Tomanova and Usseglio-Polatera (2007), and Tomanova et al. (2008) who had earlier reported these traits to be associated with impacted river systems.

Small body size $(<5 \mathrm{~mm})$ organisms were also associated with MDS in the RLQ ordination. This finding is also in line with the habitat template concept (HTC) which states that small body sized organisms favorably associate with stations that are disturbed as they are resilient to disturbance (Townsend and Hildrew, 1994). The resilience of small body sized organisms results from their ability to reproduce many offspring in one reproductive cycle, as well as their possession of large surface area to volume ratio (Townsend and Hildrew, 1994; Poff et al., 2006; Edegbene et al., 2020a), and these features possibly support the non-vulnerability of taxa that possesses small bodies to perturbed ecological health conditions.

\section{CONCLUSION}

The observed results suggest the differential distribution of traits in forested systems. Traits such as tegumental/cutaneous respiration, soft and exposed body, a preference for freeliving, burrowing, spherical body shape, FPOM, and small body size were associated with the moderately disturbed stations, suggesting that they are tolerant of human impact in forested systems. Traits such as the possessions of hardshell and complete sclerotization, preferences for clear and transparent waters, univoltinism, semivoltinism, preferences for temporary and permanent attachment, climbing and crawling, flattened body shape, cylindrical/tubular body shape, preferences for a high and moderate sensitivity to oxygen depletion, large body size, nymph aquatic stage, preferences for scrapping, shredding, and grazing which were observed at the near natural stations and slightly disturbed stations, but not at the moderately disturbed stations seemed to be sensitive to human impact in forested systems. The

\section{REFERENCES}

Adekola, O., and Mitchell, G. (2011). The Niger Delta wetlands: threats to ecosystem services, their importance to dependent communities and possible management measures. Int. J. Biodivers. Sci. Ecosyst. Serv. Manag. 7, 50-68. doi: 10.1080/21513732.2011.603138

Akamagwuna, F. C., Mensah, P. K., Nnadozie, C. F., and Odume, O. N. (2019). Traits-based responses of Ephemeroptera, Plecoptera, and Trichoptera to sediment stress in the Tsitsa River and its tributaries, Eastern Cape, South Africa. River Res. Appl. 35, 999-1012. doi: 10.1002/rra.3458

Arimoro, F. O., and Keke, U. N. (2017). The intensity of human-induced impacts on the distribution and diversity of macroinvertebrates and water quality of Gbako River in North Central Nigeria. Ecol. Energy Environ. 2, 143-154. doi: 10.1007/s40974-016-0025-8

Arimoro, F. O., Odume, O. N., Uhunoma, S. I., and Edegbene, A. O. (2015). Anthropogenic impact on water chemistry and benthic macroinvertebrate associated changes in a southern Nigeria stream. Environ. Monit. Assess. 187, 1-14. doi: 10.1007/s10661-014-4251-2

Berger, E., Haase, P., Schafer, R. B., and Sundermann, A. (2018). Towards stressorspecific macroinvertebrate indices: which traits and taxonomic groups are associated with vulnerable and tolerant taxa? Sci. Total Environ. 619, 144-154. doi: 10.1016/j.scitotenv.2017.11.022 differential distribution of traits generally indicates their value for biomonitoring. It is suggested that the trait-based approach can be further explored, with a view to developing trait-informed indices such as the proportion of sensitive invertebrate (PSI) (Extence et al., 2017) and species at risk (SPEAR) (Verberk et al., 2013) models for Afrotropical riverine systems.

\section{DATA AVAILABILITY STATEMENT}

The raw data supporting the conclusions of this article will be made available by the authors, without undue reservation.

\section{AUTHOR CONTRIBUTIONS}

$\mathrm{AE}$ and $\mathrm{OO}$ conceptualized and designed the work. $\mathrm{AE}$ and FA collected and analyzed physico-chemical variables and macroinvertebrate data. AE performed the statistical/data analyses and wrote the initial draft of the manuscript. FA, OO, $\mathrm{EO}$, and UK reviewed and edited the manuscript draft and the manuscript was finalized by AE. All authors contributed to the article and approved the submitted version.

\section{FUNDING}

This study was partly supported from the grant awarded to AE by the National Research Foundation of South Africa (NRF) and The World Academy of Sciences (TWAS), grant number: 110894.

\section{ACKNOWLEDGMENTS}

We acknowledged the effort of Miss Bawinile Mahlaba of the Institute for Water Research, Rhodes University, Grahamstown, South Africa who helped in designing the map of the study area. The technical and office assistance provided by Mrs. Edegbene Ovie Tega is highly appreciated.

Bonada, N., Prat, N., Resh, V. H., and Statzner, B. (2006). Development in aquatic insect biomonitoring: a comparative analysis of recent approaches. Annu. Rev. Entomol. 51, 495-523. doi: 10.1146/annurev.ento.51.110104. 151124

Brand, C., and Miserendino, M. L. (2015). Testing the performance of macroinvertebrate metrics as indicators changes in biodiversity after pasture conversion of Patagonian mountain streams. Water Air Soil Pollut. 226:370. doi: 10.1007/s11270-015-2633-x

Castro, D. M. P., Dolédec, S., and Callisto, M. (2018). Land cover disturbance homogenizes aquatic insect functional structure in neotropical savanna streams. Ecol. Indic. 84, 573-582. doi: 10.1016/j.ecolind.2017.09.030

Chevenet, F., Dolédec, S., and Chessel, D. (1994). A fuzzy coding approach for analysis of longterm ecological data. Freshwater Biol. 31, 295-309. doi: 10.1111/j.1365-2427.1994.tb01742.x

Descloux, S., Datry, T., and Usseglio-Polatera, P. (2014). Trait-based structure of invertebrates along a gradient of sediment colmation: benthos versus hyporheos responses. Sci. Total Environ. 466-467, 265-276. doi: 10.1016/j.scitotenv.2013.06.082

Desrosiers, M., Usseglio-Polatera, P., Archaimbault, V., Larras, F., Methot, G., and Pinel-Alloul, B. (2019). Assessing anthropogenic pressure in the St. Lawrence River using traits of benthic macroinvertebrates. Sci. Total Environ. 649, 233-246. doi: 10.1016/j.scitotenv.2018.08.267 
Dolédec, S., Chessel, D., ter Braak, C. J. F., and Champely, S. (1996). Matching species traits to environmental variables: a new three-table ordination method. Environ. Ecol. Stat. 3, 143-166. doi: 10.1007/BF02427859

Edegbene, A. O. (2020). Developing macroinvertebrate trait-and taxonomicallybased approaches for biomonitoring wadeable riverine systems in the Niger Delta, Nigeria (Ph.D thesis). Rhodes University, Grahamstown, South Africa.

Edegbene, A. O., and Arimoro, F. O. (2012). Ecological status of Owan River, Southern Nigeria using aquatic insects as bioindicators. J. Aquat. Sci. 27, 99-111.

Edegbene, A. O., Arimoro, F. O., and Odume, O. N. (2019b). Developing and applying a macroinvertebrate-based multimetric index for urban rivers in the Niger Delta, Nigeria. Ecol. Evol. 9, 12869-12885. doi: 10.1002/ece3.5769

Edegbene, A. O., Arimoro, F. O., and Odume, O. N. (2020a). Exploring the distribution patterns of macroinvertebrate signature traits and ecological preferences and their responses to urban and agricultural pollution in selected rivers in the Niger Delta ecoregion, Nigeria. Aquat. Ecol. 54, 553-573. doi: 10.1007/s10452-020-09759-9

Edegbene, A. O., Arimoro, F. O., and Odume, O. N. (2020b). How does urban pollution influence macroinvertebrate traits in forested riverine systems? Water 12:3111. doi: 10.3390/w12113111

Edegbene, A. O., Elakhame, L. A., Arimoro, F. O., Osimen, E. C., and Odume, O. N. (2019a). Development of macroinvertebrates multimetric index for ecological evaluation of a river in North Central Nigeria. Environ. Monit. Assess. 191:274. doi: 10.1007/s10661-019-7438-8

Extence, C., Richard, C., Judy, E., Marc, N., and Alex, P. (2017). Application of the Proportion of Sediment-sensitive Invertebrates (PSI) biomonitoring index. River Res. Appl. 33:1-10. doi: 10.1002/rra.3227

Fierro, P., Bertran, C., Hauenstein, E., Pena-Cortes, F., Vergara, C., Cerna, C., et al. (2017). Effects of local land-use on riparian vegetation, water quality, and the functional organisation of macroinvertebrate assemblages. Sci. Total Environ. 609, 724-734. doi: 10.1016/j.scitotenv.2017.07.197

Guilpart, A., Roussel, J. M., Aubin, M., Caquet, T., Marle, M., and Le Bris, H. (2012). The use of benthic invertebrate community and water quality analyses to assess ecological consequences of fish farm effluents in rivers. Ecol. Indic. 23, 356-365. doi: 10.1016/j.ecolind.2012.04.019

Krynak, E. M., and Yates, A. G. (2018). Benthic invertebrates taxonomic and trait associations with land use intensively managed watershed: implications for indicator identification. Ecol. Indic. 93, 1050-1059. doi: 10.1016/j.ecolind.2018.06.002

Kuzmanovic, M., Doledec, S., deCatro-Catala, N., Ginebreda, A., Sabater, S., Munoz, I., et al. (2017). Environmental stressors as driver of the trait composition of benthic macroinvertebrates assemblages in polluted Iberian rivers. Environ. Res. 156, 485-493. doi: 10.1016/j.envres.2017.03.054

Lamouroux, N., Dolédec, S., and Gayraud, S. (2004). Biological traits of stream macroinvertebrate communities: effects of microhabitat, reach, and basin filters. J. North Am. Benthol. Soc. 23, 449-466. doi: 10.1899/08873593(2004)023<0449:BTOSMC>2.0.CO;2

Lazorchak, J. M., Klemm, D. J., and Peck, D. V. (1998). Environmental Monitoring and Assessment Program Surface Waters: Field Operations and Methods Manual for Measuring the Ecological Condition of Wadeable Streams. EPA 620/R94/004F. Washington, DC: U.S. Environmental Protection Agency.

McGill, B. J., Enquist, B. J., Weiher, E., and Westoby, M. (2006). Rebuilding community ecology from functional traits. Trends Ecol. Evol. 21, 178-185. doi: $10.1016 /$ j.tree.2006.02.002

Milosevic, D., Stojanovic, K., Djurdjevic, A., Markovic, Z., Piperac, M. S., Zivic, M., et al. (2018). The response of chironomid taxonomy- and functional traitbased metric to fish effluent pollution in lotic systems. Environ. Pollut. 242, 1058-1066. doi: 10.1016/j.envpol.2018.07.100

Moares, A. B., Wilhelm, A. E., Boelter, T., Stenert, C., Schulz, U. H., and Maltchik, L. (2014). Reduced riparian zone width compromises aquatic macroinvertebrate communities in streams of southern Brazil. Environ. Monit. Assess. 186, 7063-7074. doi: 10.1007/s10661-014-3911-6

Mondy, C. P., and Usseglio-Polatera, P. (2014). Using fuzzy-coded traits to elucidate the non-random role of anthropogenic stress in the functional homogenisation of invertebrate assemblages. Freshwater Biol. 59, 584-600. doi: 10.1111/fwb.12289

Moyo, S., and Richoux, N. B. (2017). Macroinvertebrate functional organization along the longitudinal gradient of an austral temperate river. Afr. Zool. 52, 125-136. doi: 10.1080/15627020.2017.1354721
Murphy, J. F., Davy-Bowker, J., McFarland, B., and Ormerod, S. J. (2013). A diagnostic biotic index for assessing acidity in sensitive streams in Britain. Ecol. Indic. 24, 562-572. doi: 10.1016/j.ecolind.2012.08.014

Odume, O. N. (2020). Searching for urban pollution signature and sensitive macroinvertebrate traits and ecological preferences in a river in the Eastern Cape of South Africa. Ecol. Indic. 108:105759. doi: 10.1016/j.ecolind.2019.105759

Odume, O. N., Ntloko, P., Akamagwuana, F. C., Dallas, H. M., and Barber-James, H. (2018). A Trait Database for South African Macroinvertebrates. Unpublished WRC Report, Pretoria.

Oksanen, J., Blanchet, D., Minchin, P. R., O’Hara, R. B., Simpson, G. L., Solymos, P., et al. (2019). Vegan: Community Ecology Package. Available online at: https://cran.r-project.org, https://github.com/veganders/vegan (accessed February 11, 2019).

Pallottini, M., Cappelletti, D., Fabrizi, A., Gaino, E., Goretti, E., Selvaggi, R., et al. (2017). Macroinvertebrate functional trait responses to chemical pollution in agricultural landscapes. River Res. Appl. 33, 505-513. doi: 10.1002/rra.3101

Poff, N. L., Olden, J. D., Vieira, N. K. M., Finn, D. S., Simmons, M. P., and Konddratieff, B. C. (2006). Functional trait niches of North American lotic insects: traits-based ecological applications in light of phylogenetic relationships. J. North Am. Benthol. Soc. 25, 730-755. doi: 10.1899/08873593(2006)025[0730:FTNONA]2.0.CO;2

Serra, R. Q. S., Graca, M. A. S., Doledec, S., and Feio, M. J. (2017). Chironomidae traits and life history strategies as indicators of anthropogenic disturbance. Environ. Monit. Assess. 189:326. doi: 10.1007/s10661-017-6027-y

Statzner, B., and Beche, L. (2010). Can biological invertebrate traits resolve effects of multiple stressors on running water ecosystems? Freshwater Biol. 55, 80-199. doi: 10.1111/j.1365-2427.2009.02369.x

Stepenuck, K. F., Crunkilton, R. L., and Wang, L. (2002). Impacts of urban land use on macroinvertebrate communities in southerneastern Wisconsin streams. J. Am. Water Resour. Assoc. 38, 1041-1051. doi: 10.1111/j.1752-1688.2002.tb05544.x

Tomanova, S., Moya, N., and Oberdorff, T. (2008). Using macroinvertebrate biological traits for assessing biotic integrity of neotropical streams. River Res. Appl. 24, 1230-1239. doi: 10.1002/rra.1148

Tomanova, S., and Usseglio-Polatera, P. (2007). Patterns of benthic community traits in neotropical streams: relationship to mesoscale spatial variability. Fundam. Appl. Limnol. 170, 243-255. doi: 10.1127/1863-9135/2007/01 70-0243

Tonkin, J. D., Arimoro, F. O., and Haase, P. (2016). Exploring stream communities in a tropical biodiversity hotspot: biodiversity, regional occupancy, niche characteristics, and environmental correlates. Biodivers. Conserv. 25, 975-993. doi: 10.1007/s10531-016-1101-2

Townsend, C. R., and Hildrew, A. G. (1994). Species traits in relation to a habitat templet for river systems. Freshwater Biol. 31, 265-275. doi: 10.1111/j.1365-2427.1994.tb01740.x

Vannote, R. L., Minshall, G. W., Cummins, K. W., Sedell, J. R., and Cushing, C. E. (1980). The river continuum concept. Can. J. Fish. Aquat. Sci. 37, 130-137. doi: 10.1139/f80-017

Verberk, W. C. E. P., van Noordwijk, C. G. E., and Hildrew, A. G. (2013). Delivering on a promise: integrating species traits to transform descriptive community ecology into a predictive science. Freshwater Sci. 32, 531-547. doi: 10.1899/12-092.1

White, J. C., Hill, M. J., Bickerton, M. A., and Wood, P. J. (2017). Macroinvertebrate taxonomic and functional trait compositions within lotic habitats affected by river restoration practices. Environ. Manag. 60, 513-525. doi: $10.1007 / \mathrm{s} 00267-017-0889-1$

Conflict of Interest: The authors declare that the research was conducted in the absence of any commercial or financial relationships that could be construed as a potential conflict of interest.

Copyright (C) 2021 Edegbene, Arimoro, Odume, Ogidiaka and Keke. This is an openaccess article distributed under the terms of the Creative Commons Attribution License (CC BY). The use, distribution or reproduction in other forums is permitted, provided the original author(s) and the copyright owner(s) are credited and that the original publication in this journal is cited, in accordance with accepted academic practice. No use, distribution or reproduction is permitted which does not comply with these terms. 